\title{
Investigation and Analysis Report on Universities Opening Credit Management Major
}

\author{
Yuhan Wang ${ }^{1}$, Qianghui Chen ${ }^{1 *}$ and Jingyuan $\mathrm{Gao}^{1}$ \\ ${ }^{1}$ School of Economics and Management, Shanghai Polytechnic University, Shanghai 200000, China; \\ * Corresponding author
}

Keywords: Credit Management Colleges; Research; Suggestions

\begin{abstract}
The credit management major (code 020306T) is a second-level discipline under the economic discipline. The core of credit management is the control of credit risk. The credit management major was first established in 2002. The first to open this major is Renmin University of China and Shanghai University of Finance and Economics. Up to now, a total of 26 colleges and universities across the country have opened credit management major, and have delivered many excellent credit management talents to the society. However, the credit management major, as a new major, still has several problems in teaching content, professional construction and teaching resource allocation. This research is to understand the current situation of universities opening credit management major and to discover the problems existing in practical teaching of credit management. This study also provides suggestions on how to optimize the teaching system and solve existing problems.
\end{abstract}

\section{Basic Situation of the Survey}

For undergraduate institutions offering credit management, among the 26 universities opening credit management majors, there are no more than five colleges and universities recruiting postgraduates. In terms of the focus of the universities opening credit management major, the universities are divided into the research ones (include Renmin University of China, Shanghai University of Finance and Economics, Jilin University, Southwestern University of Finance and Economics, etc.) and the applied ones (include Shanghai Second Polytechnic University, Guangdong Finance College, Lixin Accounting and Finance College, etc.). And several higher vocational colleges have also opened credit management majors, such as Shanxi Vocational and Technical College and Zhejiang Industry and Trade Vocational and Technical College. Due to the credit management talents are mainly concentrated at the undergraduate level, this survey is primarily aimed at undergraduate colleges and undergraduate graduates in credit management.

1.1 Characteristics found in the investigation of undergraduate universities offering credit management majors

The survey was conducted in the form of questionnaires for the heads of 26 credit management colleges comprehensively. A total of 27 questionnaires were issued, of which 27 were valid questionnaires. For the classification and summary of 27 valid questionnaires, the following characteristics were found:

1.1.1 Universities with credit management majors focus on application mainly.

In terms of the focus of the universities opening credit management major, 22 of the respondents' colleges focused on applied research, accounting for $81.48 \%$. Only five respondents' colleges focused on theoretical research, accounting for $18.52 \%$. (Fig. 1 for details) 


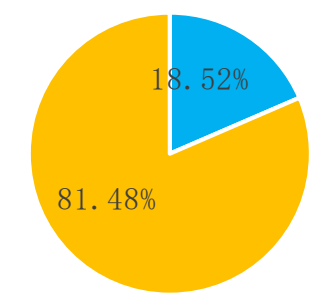

- A.Theoretical research type $\quad$ B.Applied research type

Fig. 1 Key proportion of education in credit management colleges

1.1.2 The opening time of credit management major presents a polarization trend.

As for the current number of graduates majoring in credit management in the university, there are 10 universities who have no graduates, accounting for 37.04\%. And there are eight universities who have 10 sessions of graduates and above, accounting for 29.63\%. Five have 4 to 6 sessions of graduates, accounting for $11.11 \%$.Three have 1 to 3 sessions of graduates, accounting for $11.11 \%$. Only one of the respondents who participated in the survey has 7 to 9 sessions of graduates, accounting for 3.7\%. This shows that the time for colleges to open credit management majors is in a polarized form. More than one-third of universities have only opened credit management majors in the past four years (Fig. 2 for details). Among the colleges that do not have graduates, there are 6 colleges with 1st grade students, accounting for $60.00 \%$. There are 3 universities with 3rd grade students, accounting for $30.00 \%$. One of the respondents' colleges has fourth grade students, accounting for $10.00 \%$. This shows that six colleges have only opened credit management in the past year, and three colleges have only opened credit management three years ago.

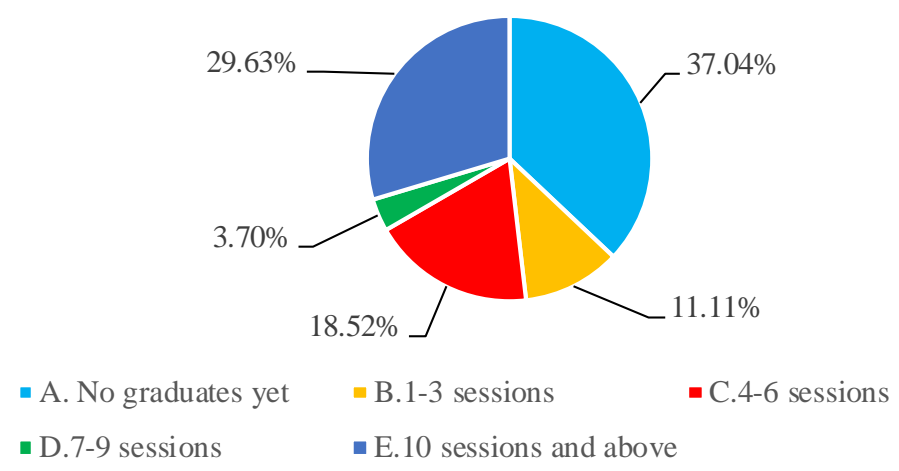

Fig. 2 the proportion of graduates majoring in credit management

1.1.3 Credit rating, credit technology theory, practice and corporate credit management are very helpful in professional learning and future employment.

For courses that are very important in credit management major learning and helpful for future work, 24 credit management respondents believe that the most helpful one is credit rating, accounting for $88.89 \%$. Followed by credit theory and practice, accounting for $66.67 \%$. Next, credit management and corporate credit management accounted for $59.26 \%$. Then there is credit risk and measurement, accounting for $51.85 \%$. Therefore, credit management colleges should open these five courses, reinforce the construction and discussion of the curriculum, and strengthen the curriculum knowledge system, which is conducive to the cultivation of professional knowledge and future employment (Fig. 3 for details). 


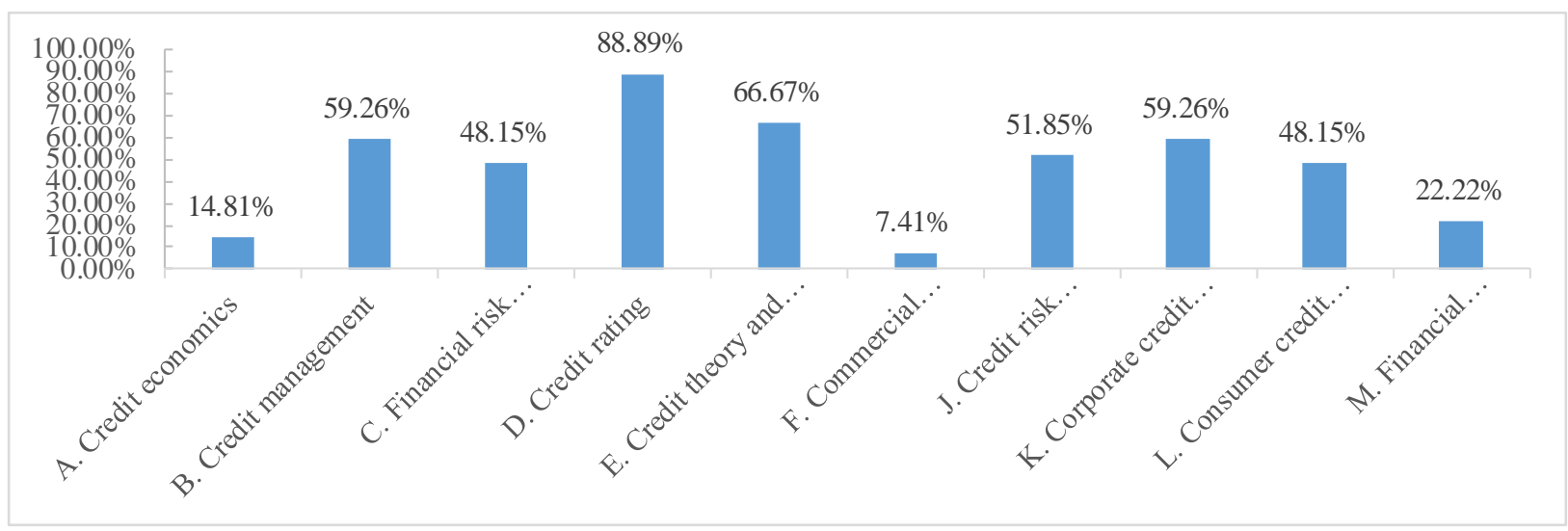

Fig. 3 shows the courses that are helpful to the future employment and the cultivation of professional knowledge

1.1.4 It is necessary for the credit management major to carry out school-enterprise cooperation.

In terms of the necessity of school-enterprise cooperation in credit management major, $81.48 \%$ of credit management respondents believe that it is very necessary to carry out school-enterprise cooperation. And $14.81 \%$ of credit management respondents believe that it is necessary to carry out school-enterprise cooperation. Only 3.7\% of credit management respondents believe that it is not necessary to carry out school-enterprise cooperation. This shows that it is very necessary to establish school-enterprise cooperation. In terms of the content of the credit management major opening school-enterprise cooperation, the most carried out is to participate in the construction of the internship training base, accept and guide students internship. The same as accepting the teachers to practice in the unit or sending technical personnel to lectures. Both of them account for $65.38 \%$. Then is to participate in professional construction and adjustment and the construction of courses and textbooks, accounting for 38.46\% (Table 1 for details). It can be seen that the cooperation between schools and enterprises is very deep, which is conducive for students to combine theory with practice and create credit management talents needed by enterprises.

Table 1 Contents of school-enterprise cooperation

\begin{tabular}{|c|c|c|}
\hline A. Participate in the construction and adjustment of major & 10 & $38.46 \%$ \\
\hline B. Participate in the construction of courses and textbooks & 10 & $38.46 \%$ \\
\hline $\begin{array}{l}\text { C. Accept the teachers to practice in the unit or send technical } \\
\text { personnel to lectures }\end{array}$ & 17 & $65.38 \%$ \\
\hline $\begin{array}{l}\text { D. Participate in the construction of the internship training base, } \\
\text { accept and guide students internship }\end{array}$ & 17 & $65.38 \%$ \\
\hline $\begin{array}{l}\text { E. Conduct skills assessment or organize and participate in skill } \\
\text { competitions }\end{array}$ & 2 & $7.69 \%$ \\
\hline F. Cooperate in technical research and development services & 0 & $0 \%$ \\
\hline $\begin{array}{l}\text { G. Participate in the development of enrollment plans and } \\
\text { arrangement of graduate employment }\end{array}$ & 5 & $19.23 \%$ \\
\hline
\end{tabular}

1.1.5 Rating companies, credit reporting companies and new financial institutions are the main targets of school-enterprise cooperation.

In terms of the types of cooperative enterprises in which the credit management major is engaged in school-enterprise cooperation, the rating companies account for $65.38 \%$. The following are credit reporting companies and new financial institutions, both of them account for 57.69\% (Table 2 for details). This shows that the correlation between enterprises that carry out school-enterprise cooperation and professions is high, which is beneficial to credit management students to learn professional knowledge. 
Table 2 Types of school-enterprise cooperation

\begin{tabular}{|l|l|c|}
\hline A. Rating company & 17 & $65.38 \%$ \\
\hline B. Credit consulting company & 15 & $57.69 \%$ \\
\hline $\begin{array}{l}\text { C. New financial institutions (Internet finance, small } \\
\text { loans, etc.) }\end{array}$ & 15 & $57.69 \%$ \\
\hline D. Finance company & 2 & $7.69 \%$ \\
\hline E. Securities firm & 1 & $3.85 \%$ \\
\hline F. Insurance company & 3 & $11.54 \%$ \\
\hline G. Commercial bank & 7 & $26.92 \%$ \\
\hline H. other & 1 & $3.85 \%$ \\
\hline
\end{tabular}

1.1.6 It is very necessary for the credit management major to obtain a certificate, especially the financial qualification certificate.

According to the pie chart of the necessity of obtaining a certificate, most of the credit management respondents consume that the acquisition of certificates is very necessary, accounting for 92.59\%. Only $7.41 \%$ of the credit management respondents believe that obtaining a certificate is unnecessary , in general the acquisition of certificates is necessary. In terms of which certificates are necessary and helpful for future employment, a qualification certificate is considered necessary to obtain, accounting for 84.00\%. Followed by authoritative professional certificates (CPA, accountants, economists, etc.), accounting for $72.00 \%$, the international qualification certificate, accounting for $56.00 \%$ (Table 3 for details). Therefore, it is necessary for credit management students to obtain financial qualifications.

Table 3 Types of Certificates

\begin{tabular}{|l|l|c|}
\hline $\begin{array}{l}\text { A. Qualification certificate (funds, securities, banks, etc.) } \\
\text { B. International qualification certificate (CFA, CIA, } \\
\text { FRM, etc.) }\end{array}$ & 21 & $84 \%$ \\
\hline $\begin{array}{l}\text { C. Authoritative professional certificate (CPA, } \\
\text { accountant, economist, etc.) }\end{array}$ & 18 & $56 \%$ \\
\hline $\begin{array}{l}\text { D. Computer certificate } \\
\text { E. English certificate }\end{array}$ & 6 & $24 \%$ \\
\hline F. other & 1 & $4 \%$ \\
\hline
\end{tabular}

\section{Problems Found in the Survey}

As a new major in China, the credit management major has no excessive experience and case to reference, and there is no unified model for each university curriculum. It is also different in professional characteristics and professional positioning. Therefore, the credit management major also has the following problems in the setting of teaching curriculum, practical teaching system, teaching material content and teaching resource allocation.

\subsection{According to the national standard, the content of courses is unreasonable and can't meet the needs of students.}

In terms of the views of the college's courses arranged according to national standards, Sixteen respondents believe that the curriculum is generally set and basically meets the needs of students, accounting for $59.26 \%$. Eight respondents believe that the course is well established and can meet the needs of students, accounting for $29.63 \%$. Three respondents think that the course is not well established and can't meet the needs of students, accounting for $11.11 \%$. Overall, 19 respondents are or not satisfied with setting courses according to the national standard, accounting for $70 \%$ (Table 4 for details). This shows that there are some problems in starting courses according to the national standard and cannot meet the needs of students. The specific performance is that professional application skills can not be reflected, accounting for $66.67 \%$. It does not meet the characteristics of the school's credit management talents 
training, accounting for 33.33\%. This shows that the main problem of dissatisfaction with the set of courses according to national standard is that the professional application skills can't be reflected.

Table 4 Satisfaction with the set of courses according to national standards

\begin{tabular}{|l|l|l|}
\hline $\begin{array}{l}\text { A. The course is well designed to meet the needs of } \\
\text { students }\end{array}$ & 8 & $29.63 \%$ \\
\hline $\begin{array}{l}\text { B. The course is generally open to meet the needs of } \\
\text { students }\end{array}$ & 16 & $59.26 \%$ \\
\hline $\begin{array}{l}\text { C. The course is not well established and cannot meet } \\
\text { the needs of students }\end{array}$ & 3 & $11.11 \%$ \\
\hline
\end{tabular}

\subsection{The teaching system is confusing and cannot meet the teaching needs.}

In terms of satisfaction with the quality of existing credit management materials on the market, 17 credit management respondents are basically satisfied with the textbooks, accounting for 62.96\%. There are 7 respondents who are dissatisfied, accounting for 25.93\%. Only 3 respondents are satisfied, accounting for $11.11 \%$. No respondents are excellently satisfied with it. This shows that there are still major problems in the textbooks of credit management at this stage, which cannot meet the use of teaching. As far as the problems exist in the existing credit management teaching materials on the market, the most response is that the content of the textbooks cannot meet the needs of teaching, accounting for $71.43 \%$. Secondly, the textbook lacks an obvious system, and there are problems of duplicate content and less textbooks on the market, accounting for $57.14 \%$ (Fig. 4 for details). This shows that the biggest problem of the current teaching materials is that the content of the teaching materials cannot meet the needs of teaching.

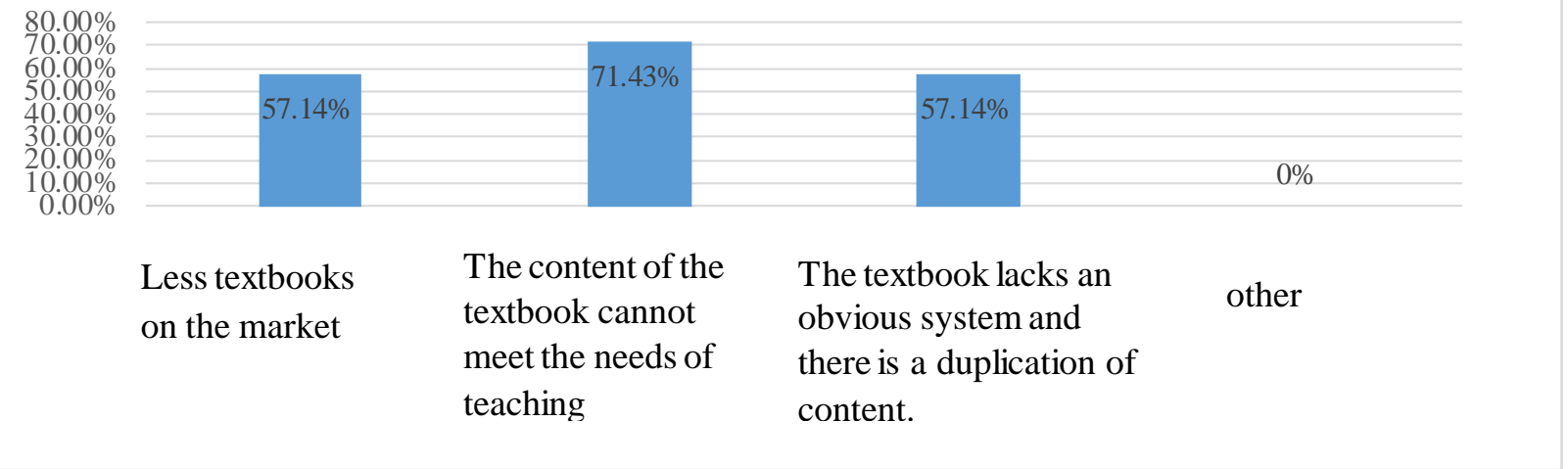

Fig. 4 Main problems in the textbook

\subsection{Insufficient allocation of teaching resources, insufficient number of teachers and funds for education.}

As far as the main problems in the education of credit management major are concerned, the main reason is that the number of teachers is insufficient, accounting for $62.96 \%$. Secondly, the teaching funds are insufficient, accounting for $48.15 \%$. What's more, the problems are the lack of case teaching and the single teaching method, accounting for $37.04 \%$ and $33.33 \%$ respectively (Table 5 for details). As an emerging profession, credit management major lacks the experience in teaching, teaching funds and teaching methods, which arise these problems.

Table 5 Problems in teaching

\begin{tabular}{|l|l|c|}
\hline A. Insufficient funds for teaching & 13 & $48.15 \%$ \\
\hline B. Unreasonable teaching plan & 4 & $14.81 \%$ \\
\hline C. Outdated teaching content & 7 & $25.93 \%$ \\
\hline D. Single teaching method & 9 & $33.33 \%$ \\
\hline E. Poor teaching management & 2 & $7.41 \%$ \\
\hline F. Teaching facilities are not perfect & 7 & $25.93 \%$ \\
\hline
\end{tabular}




\begin{tabular}{|l|l|l|}
\hline \multicolumn{3}{|c|}{ Cont to Table 5 } \\
\hline G. Ignore the cultivation of personality & 6 & $22.22 \%$ \\
\hline H. Lack of case teaching & 10 & $37.04 \%$ \\
\hline I. Insufficient teachers & 17 & $62.96 \%$ \\
\hline J. Too many students & 2 & $7.41 \%$ \\
\hline K. Inaccurate positioning of training target & 6 & $22.22 \%$ \\
\hline
\end{tabular}

2.4 The combination of teaching theory and practice is general, and some courses lack skill training.

In terms of the degree of combination of teaching theory and practice in the major of credit management, thirteen credit management respondents think it is average, accounting for $48.15 \%$. Twelve credit management respondents consider it is higher, accounting for $44.44 \%$. Only two respondents consume it is very high, accounting for $7.41 \%$. Therefore, for most of the application-oriented universities, the degree of integration of professional theory and practice of credit management should be strengthened. In terms of which courses in credit management majors require intensive skills training, 88.89\% of credit management respondents believe that professional skills training of credit rating should be enhanced. Followed by the skills training of credit technology, accounting for $77.78 \%$. Then the enterprise credit management accounts for $62.96 \%$ (Table 6 for details). Three other respondents suggest that computer information technology capabilities should be strengthened, accounting for $11.11 \%$. This shows that some professional courses lack the training of skills, and the professional training of the courses should be strengthened in the normal teaching.

Table 6 Courses need to strengthen skills training
A. Credit information technology
21
B. Credit rating
C. Corporate credit management
D. Commercial banking business 17
E. Financial Management 7
F. Econometrics
G. Assets evaluation
H. Financial institution credit management
I. Investment principles
J. other

\subsection{Professional and practical skills need to be improved.}

According to the analysis of the pie chart of the skills training situation that needs to be strengthened, 85.19\% of respondents believed that professional skills should be strengthened. The second is to strengthen practical hands-on ability, accounting for $81.48 \%$. Thirdly, the ability of interpersonal communication accounts for 37.04\% (Fig. 5 for details). Therefore, teachers should strengthen students' professional skills, practical skills and interpersonal skills in their teaching.

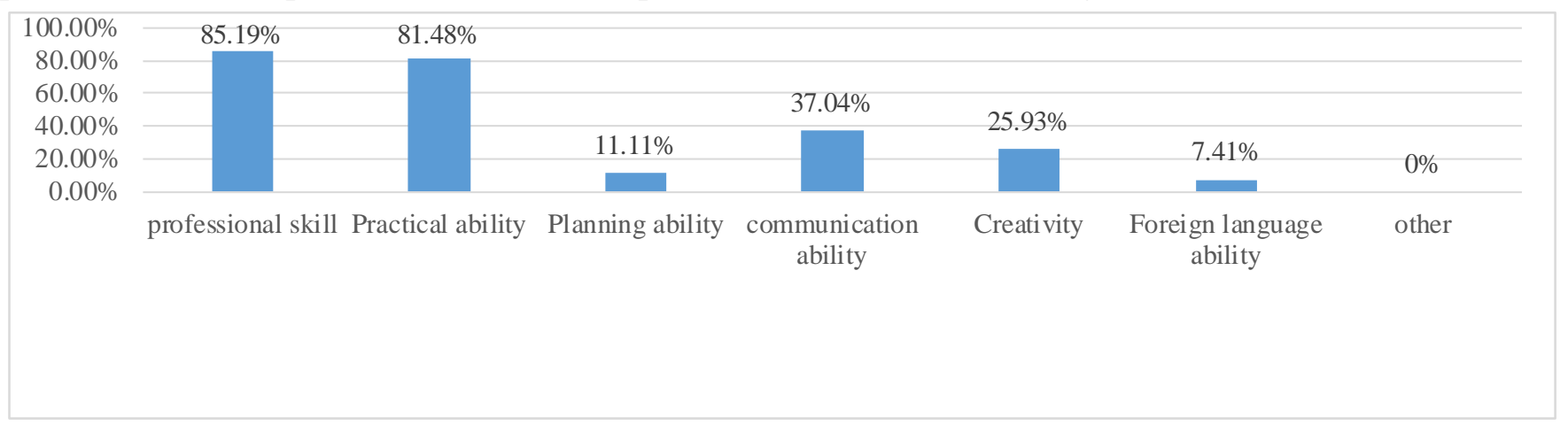

Fig. 5 Status of skills training that needs to be strengthened 


\section{Suggestions}

\subsection{Optimize the curriculum system construction.}

In the setting of specialized courses according to national standards, not only the compulsory basic courses of economics and the specialized courses of credit management are reserved, but also the special courses of credit management should be set up. Teachers in colleges should pay more attention to subject practice, and strengthen the cultivation of professional skills by giving priority to practical courses and taking theoretical courses as supplement[1]. According to the learning characteristics of this major, a more reasonable and effective curriculum system is designed around the goal of enterprises' demand for talents, and the goal orientation of curriculum design is "application" and "innovation".

\subsection{Improve the content construction of credit management teaching materials system.}

Credit management teachers from various universities can cooperate with each other and invite enterprise researchers to jointly compile textbooks for credit management, improve the content of credit management materials, and revise the duplicate chapters or missing content, and update the outdated textbooks in time. As to form a complete set of credit management professional teaching materials.

\subsection{Enhance the construction of teaching staff, enrich teaching resources and improve utilization} rate.

Firstly, intensify the introduction of credit management professionals, and recruit high-level credit talents to enrich the teaching staff by recruiting fresh doctoral graduates or credit management talents of famous universities. Secondly, establish a research incentive mechanism and cooperate with related enterprises. Dispatch full-time teachers to credit management enterprises or financial institutions to take exercise, so as to improve the quality of teachers and their awareness of professional work. Meanwhile, invite senior executives or front-line employees of credit management corporate to give lectures to students to strengthen their recognition of their majors[2]. Thirdly, teachers should be encouraged to study for a doctoral degree, study abroad and participate in social practice to improve their professional knowledge and skills, so as to rationalize the teacher structure and improve the teaching echelon. In addition, create a school-enterprise exchange platform to complement each other, improve teachers' awareness of the industry's dynamics, and create conditions for reforming and enriching teaching content, providing theoretical research and practical topics, and enhancing the value of theoretical research[3]. Last but not the least, increase capital investment and optimize the allocation of educational resources, such as purchasing professional software, building a training base and making reasonable use of teaching funds to create maximum value.

\subsection{According to the nature of each university to set up the curriculum that meets the characteristics of talent cultivation.}

Each university has different orientations for credit management talents, and its professional characteristics and training direction are also different. Therefore, each university should set up courses according to the characteristics of talent cultivation. For universities that focus on application, they should pay attention to the cultivation of their practical ability and set up application-oriented courses. For universities that focus on theory, they should focus on cultivating their research and analysis capabilities.

\subsection{Building an innovative and applied talent training model.}

The request of this major's application type is higher. When the credit management colleges cultivate credit talents, they should not only pay attention to the cultivation of credit theoretical knowledge, but also pay attention to the cultivation of practical ability.

Design the cultivation mode of credit talents oriented by the needs of enterprises, and cultivate applied, innovative and composite credit management talents by relying on the high-level teaching team of the school and the learning of internal and external training skills. The cultivation method of combining on-campus training with off-campus practice enables students to have a solid theoretical foundation of credit, carry out school-enterprise cooperation, and strengthen the training of professional skills. The students' practical skills and innovative abilities are cultivated through a combination of intramural training and off-campus practice. 


\section{Conclusion}

Through this investigation, it is found that there are still a series of problems in the practical teaching of universities offering credit management majors, such as unreasonable course setting, chaotic teaching material system and lack of teachers. Therefore, the future development of the major will be carried out from the aspects of optimizing the curriculum system design, strengthening the construction of teaching material system and introducing professional teachers. In these ways to cultivate innovative and applied professional talents and provide high-quality professional personnel for the society.

\section{Acknowledgment}

Thanks for the financial support of XXKPY1602.

\section{References}

[1]. Guoqin, X. U. "Summary of Professional Education of Domestic Credit Administration." Journal of Tianjin R \& TV University (2007). (In Chinese)

[2]. Cai, Sainan, L. Huang, and C. M. Department. "Probing into the Phenomenon of Graduated Collegians' Pre-employment Breaching Contract-A Case Study of Guangdong University of Finance." Credit Reference (2017). (In Chinese)

[3]. Zeng J, Yao D, Li-Xia Y U. Research on the Current Situation and Problems of Credit Management in China-Based on the Perspective of Constitutive Elements of Talent Training Mode[J]. Journal of Chengdu Normal University, 2017. (In Chinese) 